\title{
Polymer-Coated Urea Delays Growth and Accumulation of Key Nutrients in Aerobic Rice but Does Not Affect Grain Mineral Concentrations
}

\author{
Terry J. Rose \\ Southern Cross Plant Science, Southern Cross University, PO Box 157 Lismore, NSW 2480, Australia; \\ terry.rose@scu.edu.au; Tel.: +61-2-6620-3457 \\ Academic Editor: Gareth J. Norton \\ Received: 30 July 2015; Accepted: 25 January 2016; Published: 28 January 2016
}

\begin{abstract}
Enhanced efficiency nitrogen (N) fertilizers (EEFs) may improve crop recovery of fertilizer-N, but there is evidence that some EEFs cause a lag in crop growth compared to growth with standard urea. Biomass and mineral nutrient accumulation was investigated in rice fertilized with urea, urea-3,4-dimethylpyrazole phosphate (DMPP) and polymer-coated urea (PCU) to determine whether any delays in biomass production alter the accumulation patterns, and subsequent grain concentrations, of key mineral nutrients. Plant growth and mineral accumulation and partitioning to grains did not differ significantly between plants fertilized with urea or urea-DMPP. In contrast, biomass accumulation and the accumulation of phosphorus, potassium, calcium, magnesium, copper, zinc and manganese were delayed during the early growth phase of plants fertilized with PCU. However, plants in the PCU treatment ultimately compensated for this by increasing growth and nutrient uptake during the latter vegetative stages so that no differences in biomass or nutrient accumulation generally existed among $\mathrm{N}$ fertilizer treatments at anthesis. Delayed biomass accumulation in rice fertilized with PCU does not appear to reduce the total accumulation of mineral nutrients, nor to have any impact on grain mineral nutrition when biomass and grain yields are equal to those of rice grown with urea or urea-DMPP.
\end{abstract}

Keywords: controlled-release urea; nitrification inhibitor; nitrogen; phosphorus

\section{Introduction}

Global crop production relies heavily on the application of nitrogen $(\mathrm{N})$ fertilizers to sustain high yields, and global demand for $\mathrm{N}$ fertilizers is predicted to increase further over the next decade [1]. Unfortunately, the $\mathrm{N}$ use efficiency of crop production is generally low, with crops rarely assimilating more than $50 \%$ of the fertilizer $\mathrm{N}$ applied [2]. While some of the fertilizer $\mathrm{N}$ is retained in the soil and may be available for uptake by subsequent crops, much of the $\mathrm{N}$ applied to crops and pastures is lost through leaching [3,4] or emitted as the gases $\mathrm{NH}_{3}$ or $\mathrm{N}_{2} \mathrm{O}$ [5,6]. An unintended consequence of these losses is environmental damage, predominantly eutrophication of waterways due to $\mathrm{N}$ contamination, and increasing greenhouse gas emissions from agriculture as a result of $\mathrm{N}_{2} \mathrm{O}$ losses [2].

A number of agronomic management strategies have been suggested for enhancing $\mathrm{N}$ efficiency, including optimising $\mathrm{N}$ budgeting, $\mathrm{N}$ fertilizer placement, and timing $[7,8]$ to better match soil $\mathrm{N}$ supply patterns with crop $\mathrm{N}$ demand. Another option is to use enhanced-efficiency fertilizers (EEF), which broadly comprise controlled-release $\mathrm{N}$ fertilizers and $\mathrm{N}$ fertilizers with urease or nitrification inhibitors [2]. A number of studies have investigated the impact of EEF vs. urea on crop yields, $\mathrm{N}$ use efficiency or nitrous oxide losses in dryland crops [9-11]. While $\mathrm{N}$ use efficiency was improved in some instances, the delayed $\mathrm{N}$ availability from controlled-release $\mathrm{N}$ fertilizers was also observed to delay biomass production, and ultimately reduce yield, compared to urea application in some seasons [10]. 
As yet, the impact of any delayed biomass accumulation pattern from EEFs on the accumulation of other mineral nutrients in crops, and the consequences for grain nutritional content, is not known. While delayed early nutrient accumulation can be compensated by increased uptake in later growth stages, moisture stress in later growing stages can limit nutrient uptake in a nutrient-specific manner [12]. Any impact on the concentrations of magnesium (Mg), calcium, (Ca), zinc ( $\mathrm{Zn})$ and copper $(\mathrm{Cu})$ in grains are of particular importance because deficiencies of these nutrients in the diet are a major health concern [13]. The aim of the present study was to investigate whether any changes in growth patterns caused by EEF alter the accumulation of key nutrients in aerobically-cultivated rice (Oryza sativa L.) and whether these alterations impact on grain nutritional quality.

\section{Results}

The accumulation of biomass, phosphorus (P), Mg, manganese (Mn) and $\mathrm{Zn}$ generally continued until maturity regardless of $\mathrm{N}$ fertilizer treatment, while peak accumulation of $\mathrm{N}, \mathrm{Ca}$ and $\mathrm{Cu}$ generally occurred during early grain filling (108 days after sowing [DAS]) regardless of $\mathrm{N}$ fertilizer treatment (Figure 1). Peak accumulation of potassium (K) occurred earlier, at anthesis (93 DAS) in the urea and urea-3,4-dimethylpyrazole phosphate (DMPP) treatments, but at early grain filling (108 DAS) in the polymer-coated urea (PCU) treatment (Figure 1d).
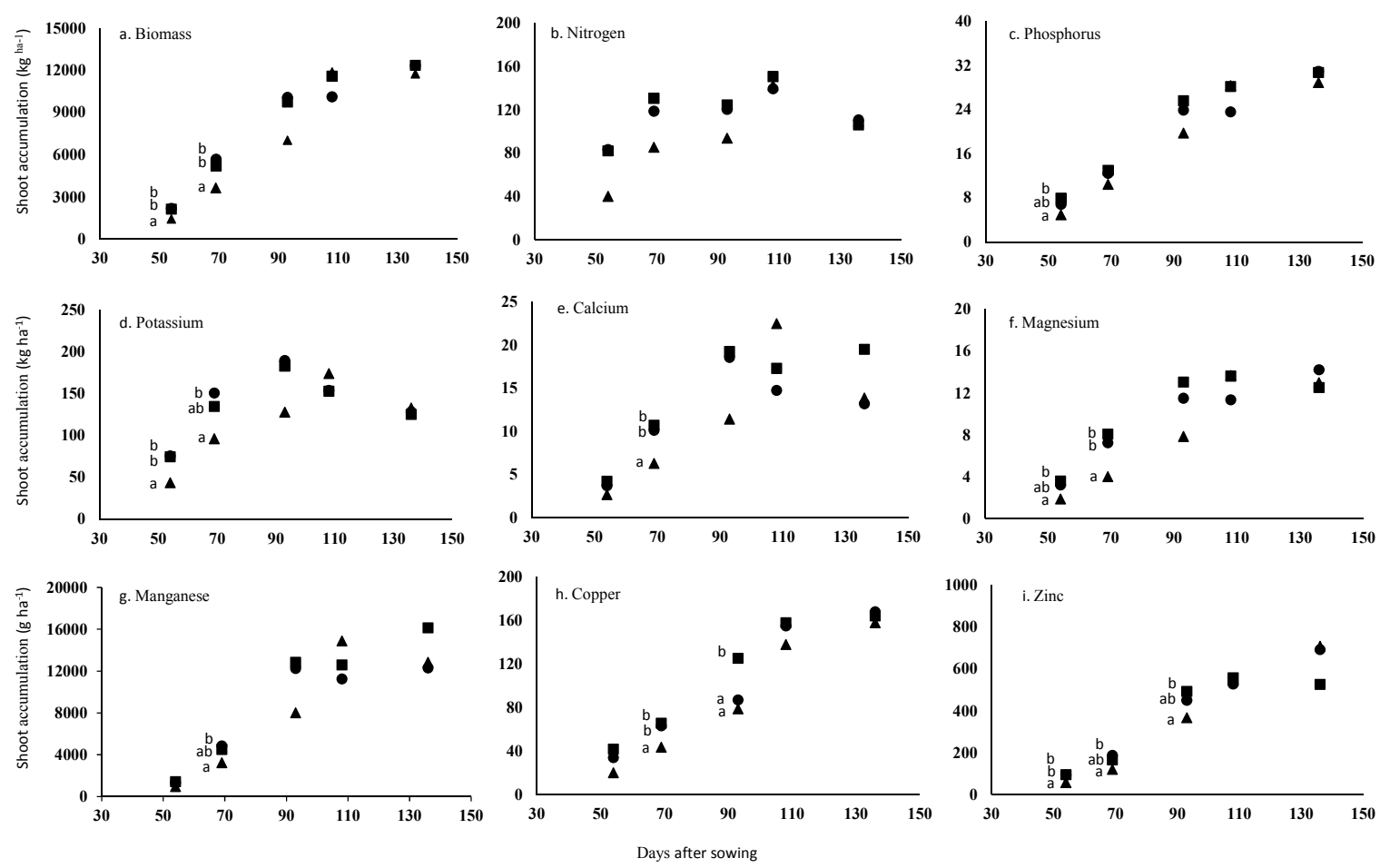

Figure 1. Accumulation of biomass (a), nitrogen (b), phosphorus (c), potassium (d), calcium (e), magnesium (f), manganese $(\mathbf{g})$, copper $(\mathbf{h})$ and zinc (i) throughout the growing season in shoots of rice fertilized with urea (circles), urea + urea-3,4-dimethylpyrazole phosphate (DMPP) (squares) or polymer-coated urea (triangles). Treatments that do share a common letter within a given harvest (timepoint) are not significantly different at a $p \leqslant 0.05$. The absence of any letters at a given harvest (timepoint) indicates no significant differences among treatments.

Biomass data confirmed visual observations of delayed early growth in the PCU treatment, with significant reductions in biomass production at 54 DAS and 69 DAS in the PCU treatment compared to urea and urea-3,4-dimethylpyrazole phosphate (DMPP) treatments (Figure 1a). Despite these growth reductions, no significant reduction in early shoot $\mathrm{N}$ accumulation was observed in the PCU treatment at $p=0.05$ (Figure 1b), although reductions were observed at $p<0.1$ at 54 DAS. Notably, the urea-DMPP 
treatment did not result in increased shoot $\mathrm{N}$ accumulation compared to urea at any growth stage (Figure 1b).

The accumulation of macronutrients $\mathrm{P}, \mathrm{K}, \mathrm{Ca}$ and $\mathrm{Mg}$ was reduced in the PCU treatment compared to either or both of urea and urea-DMPP treatments at 54 DAS, 69 DAS or both harvest dates (Figure 1c-f). Similarly, the accumulation of the micronutrients Mn, $\mathrm{Cu}$ and $\mathrm{Zn}$ were delayed in the PCU treatment, with significantly lower shoot Mn (69 DAS), $\mathrm{Cu}(69$ and 93 DAS) and $\mathrm{Zn}$ (54, 69 and 93 DAS) contents in the PCU treatment compared to urea-DMPP and urea treatments $(p<0.05$; Figure 1g-i).

Grain yield and harvest index (proportion of crop biomass in grains at maturity) did not differ among treatments, with means of $5.07 \mathrm{t} \cdot \mathrm{ha}^{-1}$ and 0.42 (Table 1). Similarly, N fertilizer treatment had no impact on grain nutrient concentrations and nutrient harvest indices (Table 1).

Table 1. Average rice nutrient harvest indices and grain nutrient concentrations in the field trial. Note: data are means from all three $\mathrm{N}$ treatments since there was no significant $(p=0.05)$ effect of $\mathrm{N}$ fertilizer type on grain yield, nutrient harvest indices or grain nutrient concentrations.

\begin{tabular}{|c|c|c|c|c|c|c|c|c|c|}
\hline & \multirow[t]{2}{*}{ Grain Yield $\left(t \cdot h^{-1}\right)$} & \multicolumn{5}{|c|}{ Macronutrients $\left(\mathrm{mg} \cdot \mathrm{g}^{-1}\right)$} & \multicolumn{3}{|c|}{ Micronutrients $\left(\mathrm{mg} \cdot \mathrm{kg}^{-1}\right)$} \\
\hline & & $\mathrm{N}$ & $\mathrm{P}$ & $\mathrm{K}$ & $\mathrm{Ca}$ & $\mathrm{Mg}$ & $\mathrm{Cu}$ & $\mathrm{Mn}$ & $\mathrm{Zn}$ \\
\hline $\begin{array}{l}\text { Grain nutrient } \\
\text { concentration }\end{array}$ & 5.08 & 12.4 & 3.44 & 4.03 & 0.22 & 1.23 & 20.6 & 197 & 36.1 \\
\hline Nutrient harvest index & 0.42 & 0.55 & 0.58 & 0.16 & 0.07 & 0.47 & 0.64 & 0.07 & 0.29 \\
\hline
\end{tabular}

\section{Discussion}

Controlled-release urea fertilizers have a sigmoidal $\mathrm{N}$ release pattern compared to the rapid mineralisation of urea $\mathrm{N}$ [14] and this resulted in the delayed biomass production in the CRU treatment compared to the urea and urea-DMPP treatments in the present study (Figure 1a). This delayed biomass production clearly demonstrates that, in the absence of other constraints, the availability of $\mathrm{N}$ heavily impacts on growth rates of upland rice, which has also been observed under varying $\mathrm{N}$ fertilizer regimes in flooded rice [15]. While urea-DMPP has been shown to reduce nitrification rates in controlled environments [16] and temperate environments [17], evidence in warmer subtropical environments is lacking. While nitrification rates were not measured in the present study, the fact that the urea-DMPP treatment had no impact on biomass production or $\mathrm{N}$ uptake compared to urea suggests that any effect of urea-DMPP on N dynamics is limited in subtropical conditions.

The macronutrient accumulation patterns throughout the season were typical of rice, with accumulation of biomass and $\mathrm{P}$ continuing until maturity while $\mathrm{N}$ and $\mathrm{Ca}$ accumulation peak during early grain filling [18]. The decline in the shoot $\mathrm{K}$ content between anthesis and maturity observed in the present study was also observed by Garcia et al. [18] and the same phenomenon occurs in wheat [19], although the reason for this net loss of $\mathrm{K}$ is not known. Nutrient concentrations in rice grains were also typical of the concentrations observed in field-grown rice [20].

The altered growth patterns in the PCU treatment affected the accumulation of key nutrients in shoots with significantly $(p<0.05)$ delayed uptake of all nutrients at one or more of the vegetative growth stages (tillering, jointing and anthesis). The exception was N (Figure 1), whose delayed accumulation was only significant at $p<0.1$. This reflects the high variability in the $\mathrm{N}$ accumulation data, which is likely related to the uneven distribution of sugarcane (Saccharum officinarum L.) trash from the previous crop. Ultimately, however, there were no differences in nutrient accumulation among $\mathrm{N}$ fertilizer treatments at anthesis (93 DAS)-with the exception of $\mathrm{Zn}$-and no differences in grain mineral concentrations at maturity (Table 1). In other words, nutrient uptake in all $\mathrm{N}$ treatments was finally congruent as the biomass production was also congruent. However, it is noteworthy that the 2014-2015 season was a wet season, with $>500 \mathrm{~mm}$ precipitation falling from January-April. In seasons where topsoil drying is prevalent during mid-late summer (late tillering to anthesis, from around 60 DAS to 93 DAS in the present study) and PCU-treated crops have higher biomass and nutrient accumulation rates, it is possible that the uptake of nutrients such as $\mathrm{P}$ and $\mathrm{Zn}$, which are 
predominantly located in the $0-10 \mathrm{~cm}$ horizon (Table 2), may be restricted [21]. Moreover, by the same reasoning it is also possible that topsoil drying events earlier in the season may restrict the uptake of $\mathrm{P}$ and $\mathrm{Zn}$ in crops supplied with urea. In summary, there is no clear evidence that the delayed biomass accumulation observed in crops fertilised with PCU reduces the total accumulation of mineral nutrients in rice or has any impact on grain mineral nutrition when biomass and grain yields do not differ from crops fertilised with urea.

\section{Experimental Section}

A field trial was conducted near Woodburn, NSW, Australia, in the summer of 2014-2015, in a field previously under sugarcane. In the 5-month period following sugarcane harvest, the soil was rotary hoed twice, followed by offset discing, then rotary hoed twice more, and power harrowed immediately prior to planting rice. Soil samples were collected immediately prior to sowing and physiochemical properties are shown in Table 2.

Following the application of a pre-emergent herbicide $\left(480 \mathrm{~g} \cdot \mathrm{L}^{-1}\right.$ Clomazone at $\left.600 \mathrm{~mL} \cdot \mathrm{ha}^{-1}\right)$, rice (cv. Tachiminori) was sown on 7 December 2014 at $125 \mathrm{~kg}$. seed $\cdot \mathrm{ha}^{-1}$ using a tined seeder at a row spacing of $150 \mathrm{~mm}$. Plots $3 \mathrm{~m} \times 8 \mathrm{~m}$ were established in triplicate 4 weeks after sowing to accommodate a completely randomized block trial investigating the impact of $\mathrm{N}$ fertilizer source on the accumulation of mineral nutrients in rice. The three $\mathrm{N}$ treatments were $80 \mathrm{~kg} \cdot \mathrm{ha}^{-1} \mathrm{~N}$ applied as urea, a commercial product with urea + 3,4-dimethylpyrazole phosphate (DMPP) at $1.84 \mathrm{~kg}$ DMPP active ingredient/ $t$ urea, and a commercial polymer-coated urea product (PCU). Fertilizer $\mathrm{N}$ rates above $80 \mathrm{~kg} \cdot \mathrm{ha}^{-1}$ in this region typically increase $\mathrm{N}$ uptake and grain yields but lead to severe crop lodging (unpublished data) and are not recommended.

Fertilizer-N was applied at around 35 DAS to avoid the accumulation of excess mineral $\mathrm{N}$ in the soil during early growth. The 5 months fallow period prior to rice planting in the rice-cane rotation in the Australian subtropics allows mineralization of organic N, and hence, around $100 \mathrm{~kg} \cdot \mathrm{ha}^{-1}$ mineral $\mathrm{N}$ was present in the soil to $900 \mathrm{~mm}$ depth assuming a bulk density of around $1 \mathrm{~g} \cdot \mathrm{cm}^{-3}$ (Table 2). Rainfall during the growing season recorded from the nearby Woodburn weather station was January-200 mm, February-217 mm, March-47 mm, and April-160 mm.

Table 2. Selected physiochemical properties of the 0-100 mm, 100-300 mm, 300-600 mm and 600-900 $\mathrm{mm}$ horizons at the Woodburn field site.

\begin{tabular}{|c|c|c|c|c|}
\hline \multirow[b]{2}{*}{ Property } & \multicolumn{4}{|c|}{ Soil Depth (mm) } \\
\hline & 0-100 & $100-300$ & $300-600$ & $600-900$ \\
\hline Basic texture & clay loam & clay & clay & clay \\
\hline Total carbon (\%) & 2.3 & 2.1 & 1.1 & 2.1 \\
\hline Total nitrogen $(\%)$ & 0.18 & 0.16 & 0.09 & 0.21 \\
\hline $\mathrm{KCl}$ extractable ammonium $\left(\mathrm{mg} \cdot \mathrm{kg}^{-1}\right)$ & 9.9 & 11.3 & 12.5 & 12.2 \\
\hline $\mathrm{KCl}$ extractable nitrate $\left(\mathrm{mg} \cdot \mathrm{kg}^{-1}\right)$ & 0.90 & 1.3 & 0.9 & 1.2 \\
\hline $\mathrm{pH}(1: 5$ water $)$ & 5.57 & 5.50 & 5.35 & 5.50 \\
\hline $\mathrm{EC}\left(\mathrm{dS} \cdot \mathrm{m}^{-1}\right)$ & 0.04 & 0.05 & 0.06 & 0.07 \\
\hline Bray 1 phosphorus $\left(\mathrm{mg} \cdot \mathrm{kg}^{-1}\right)$ & 14.8 & 6.0 & 5.9 & 1.5 \\
\hline Total acid extractable sulfur $\left(\mathrm{mg} \cdot \mathrm{kg}^{-1}\right)$ & 411 & 427 & 806 & 379 \\
\hline Cation exchange capacity $\left(\mathrm{cmol}^{+} \cdot \mathrm{kg}^{-1}\right)$ & 27.3 & 27.3 & 25.0 & 26.3 \\
\hline \multicolumn{5}{|l|}{ Base cations $(\%)$} \\
\hline Calcium & 54.3 & 52.0 & 42.0 & 41.7 \\
\hline Magnesium & 36.8 & 36.8 & 40.9 & 40.0 \\
\hline Potassium & 2.3 & 1.8 & 1.5 & 1.2 \\
\hline Sodium & 1.3 & 1.6 & 2.3 & 4.9 \\
\hline Aluminium & 3.2 & 4.7 & 8.6 & 8.3 \\
\hline \multicolumn{5}{|l|}{ DPTA-extractable micronutrients } \\
\hline Zinc $\left(\mathrm{mg} \cdot \mathrm{kg}^{-1}\right)$ & 2.5 & 1.3 & 1.3 & 0.9 \\
\hline Manganese $\left(\mathrm{mg} \cdot \mathrm{kg}^{-1}\right)$ & 13 & 9 & 8 & 4 \\
\hline $\operatorname{Iron}\left(\mathrm{mg} \cdot \mathrm{kg}^{-1}\right)$ & 221 & 209 & 177 & 127 \\
\hline Copper $\left(\mathrm{mg} \cdot \mathrm{kg}^{-1}\right)$ & 1.0 & 0.6 & 0.9 & not detectable \\
\hline
\end{tabular}


Samples were measured at Environmental Analysis Laboratories (EAL), Southern Cross University, Lismore, Australia, using methods from Rayment and Lyons [22].

\subsection{Measurements}

Aboveground plant tissue was harvested at tillering (54 DAS), jointing (69 DAS), anthesis (93 DAS), mid grain filling (108 DAS) and maturity (136 DAS) by cutting two 1 m-lengths of row per plot at ground level. At maturity, samples were threshed by hand to separate grain and straw. All samples were dried in an air-forced oven at $60^{\circ} \mathrm{C}$ for 5 days. Samples were analysed for nutrient concentration at Environmental Analysis Laboratories, Lismore, NSW, Australia. A $0.2 \mathrm{~g}$ subsample of finely ground tissue was digested with nitric acid in a MARS microwave oven (CEM Corp., USA) and concentrations of $\mathrm{P}, \mathrm{K}, \mathrm{Mg}, \mathrm{Ca}, \mathrm{Zn}, \mathrm{Mn}$, and $\mathrm{Cu}$ in the digest solutions were quantified using inductively coupled plasma optical emission spectroscopy (ICP-OES 4300D, Perkin Elmer, USA). Tissue N concentration was measured using a LECO TruMAC CNS analyser. The accumulation of sulphur (S) and iron (Fe) was not investigated because soils in the region are rich in these nutrients due to the presence of pyrite $\left(\mathrm{FeS}_{2}\right)$ in the subsoil [23], which results in excessive, rather than limiting, levels of $\mathrm{S}$ and $\mathrm{Fe}$ in crops grown.

\subsection{Statistical Analyses}

Nutrient accumulation, nutrient harvest index and grain nutrient concentration data were analysed using a two-way analysis of variance fitting $\mathrm{N}$ fertilizer treatment and block (replicate) in Genstat using a probability level of 0.05 . Significance of differences between treatment mean values for each trait was tested using Duncan's multiple range test.

\section{Conclusions}

The use of PCU fertilizer caused a significant delay in early biomass production compared to both urea and urea-DMPP fertilizers, but ultimately this did lead to any reduction in the total accumulation of mineral nutrients at maturity or reductions in grain nutrient concentrations. However, it is possible that in seasons with a dry finish that limits nutrient uptake the delay in early growth observed in plants fertilized with PCU may have greater impacts on grain nutritional quality.

Conflicts of Interest: The author declares no conflict of interest.

\section{References}

1. Timilsena, Y.P.; Adhikari, R.; Casey, P.; Muster, T.; Gill, H.; Adhikari, B. Enhanced efficiency fertilizers: A review of formulation and nutrient release patterns. J. Sci. Food Agric. 2015, 95, 1131-1142. [CrossRef] [PubMed]

2. Chen, D.; Suter, H.; Islam, A.; Edis, R.; Freney, J.R.; Walker, C.N. Prospects of improving efficiency of fertilizer nitrogen in Australian agriculture: A review of enhanced efficiency fertilizers. Soil Res. 2008, 46, $289-301$. [CrossRef]

3. Burkitt, L.L. A review of nitrogen losses due to leaching and surface runoff under intensive pasture management in Australia. Soil Res. 2014, 52, 621-636. [CrossRef]

4. Zhou, M.; Butterbach-Bahl, K. Assessment of nitrate leaching loss on a yield-scaled basis from maize and wheat cropping systems. Plant Soil 2014, 374, 977-991. [CrossRef]

5. Macdonald, B.C.T.; Denmead, O.T.; White, I. Quantification of $\mathrm{NOx}$ and $\mathrm{NH}_{3}$ emissions from two sugarcane fields. Soil Res. 2014, 52, 833-840. [CrossRef]

6. Schwenke, G.D.; Manning, W.; Haigh, B.M. Ammonia volatilisation from nitrogen fertilizers surface-applied to bare fallows, wheat crops and perennial-grass-based pastures on Vertosols. Soil Res. 2014, 52, 805-821. [CrossRef]

7. Nelson, K.A.; Motavalli, P.P.; Nathan, M. Nitrogen fertilizer sources and application timing affects wheat and inter-seeded red clover yields on claypan soils. Agronomy 2014, 4, 497-513. [CrossRef] 
8. Shenwu, L.; Wang, X.; Liu, G. A simple and reasonable calculation equation of balanced fertilization. Agronomy 2015, 5, 180-187.

9. Mahli, S.S.; Soon, Y.K.; Grant, C.A.; Lemke, R.; Lupwayi, N. Influence of controlled-release urea on seed yield and $\mathrm{N}$ concentration and $\mathrm{N}$ use efficiency of small grain crops grown on Dark Gray Luvisols. Can. J. Soil Sci. 2010, 90, 363-372.

10. Grant, C.A.; Wu, R.; Selles, F.; Harker, F.N.; Clayton, G.W.; Bittman, S.; Zebarth, B.J.; Lupwayi, N.Z. Crop yield and nitrogen concentration with controlled release urea and split applications of nitrogen as compared to non-coated urea applied at seeding. Field Crop Res. 2012, 127, 170-180. [CrossRef]

11. Gao, X.; Asgedom, H.; Tenuta, M.; Flaten, D.N. Enhanced efficiency urea sources and placement effects on nitrous oxide emissions. Agron. J. 2015, 107, 265-277. [CrossRef]

12. Rose, T.J.; Bloomfield, C.; Raymond, C.; King, G.J. Perturbation of nutrient source-sink relationships by post-anthesis stresses results in differential accumulation of key nutrients into wheat grain. J. Plant Nutr. Soil Sci. 2015, 178, 89-98. [CrossRef]

13. White, P.J.; Broadley, M.R. Biofortification of crops with seven mineral elements often lacking in human diets-iron, zinc, copper, calcium, magnesium, selenium and iodine. New Phytol. 2009, 182, 49-84. [CrossRef] [PubMed]

14. Chalk, P.M.; Craswell, E.T.; Polidoro, J.C.; Chen, D. Fate and efficiency of ${ }^{15} \mathrm{~N}$-labelled slow- and controlled release fertilizers. Nutr. Cycl. Agroecosyst. 2015. [CrossRef]

15. Dunn, B.W.; Dunn, T.S.; Beecher, H.G. Nitrogen timing and rate effects on growth and grain yield of delayed permanent-water rice in south-eastern Australia. Crop Pasture Sci. 2014, 65, 878-887. [CrossRef]

16. Chen, D.; Suter, H.; Islam, A.; Edis, R. Influence of nitrification inhibitors on nitrification and nitrous oxide $\left(\mathrm{N}_{2} \mathrm{O}\right)$ emission from a clay loam soil fertilized with urea. Soil Biol. Biochem. 2010, 42, 660-664. [CrossRef]

17. Weiske, A.; Benckiser, G.; Ottow, J.C.G. Effect of the new nitrification inhibitor DMPP in comparison to DCD on nitrous oxide $\left(\mathrm{N}_{2} \mathrm{O}\right)$ emissions and methane $\left(\mathrm{CH}_{4}\right)$ oxidation during 3 years of repeated applications in field experiments. Nutr. Cycl. Agroecosyst. 2001, 60, 57-64. [CrossRef]

18. Garcia, A.G.; Douradeo-Neto, D.; Basanta, M.D.V.; Ovejero, R.F.L.; Favarin, J.L. Logistic rice model for dry matter and nutrient uptake. Sci. Agric. 2003, 60, 481-488.

19. Rose, T.J.; Rengel, Z.; Bowden, J.; Ma, Q. Differential accumulation of phosphorus and potassium by canola cultivars compared to wheat. J. Soil Sci. Plant Nutr. 2007, 170, 404-411. [CrossRef]

20. Dobermann, A.; Fairhurst, T.H. Nutrient Disorders and Nutrient Management; Potash and Phosphate Institute, Potash and Phosphate Institute of Canada and International Rice Research Institute: Singapore, 2000.

21. Ma, Q.; Rengel, Z.; Rose, T.J. The effectiveness of deep placement of fertilizers is determined by crop species and edaphic conditions in Mediterranean-type environments: A review. Aust. J. Soil Res. 2009, 47, 19-32. [CrossRef]

22. Rayment, G.E.; Lyons, D.J. Australian Laboratory Handbook of Soil and Water Chemical Methods; Inkata Press: Port Melbourne, Australia, 2011.

23. Huang, J.; Nhan, T.; Wong, V.N.L.; Johnston, S.G.; Lark, M.; Triantafilis, J. Digital soil mapping of a coastal acid sulfate soil landscape. Soil Res. 2014, 52, 327-339. [CrossRef]

(C) 2016 by the author; licensee MDPI, Basel, Switzerland. This article is an open access article distributed under the terms and conditions of the Creative Commons by Attribution (CC-BY) license (http:/ / creativecommons.org/licenses/by/4.0/). 